\title{
Sınıf Öğretmenliği Öğretmen Adaylarının Geliştirdikleri Mühendislik Tasarım Temelli Fen Öğretim Etkinliklerinin Değerlendirilmesi
}

\section{Ayşegül KINIK TOPALSAN*}

Öz: Güncellenen Fen Bilimleri dersi öğretim programına, Fen ve Mühendislik Uygulamaları konu alanı eklenerek konu alanı sayısı 4 ten 5 çıkarılmıştır. Bu alan, fen bilimlerinin matematik, teknoloji ve mühendislikle bütünleştirilmesi sağlanarak, problemlere disiplinler arası bakış açısı kazandırmasını, öğrencileri buluş ve inovasyon yapabilme seviyesine ulaştırarak, edindikleri bilgi ve beceriler sayesinde ürün oluşturmalarını ve bu ürünlere nasıl katma değer kazandırılabilecekleri konusunda ki genel stratejileri kapsamaktadır. Bu becerileri geliştirmesi beklenen öğretmenlerin, FeTeMM alanındaki becerileri geliştirilmeli ve öğrencileri etkin kılacak öğretim etkinlikleri üretip uygulamaları sağlanmalıdır. Bu kapsamda, bu çalışmada İstanbul Aydın Üniversitesi Eğitim Fakültesi Sınıf Öğretmenliği programında verilen Fen ve Teknoloji Öğretimi-II dersi kapsamında, verilen eğitimler sonrasında, öğretmen adaylarının Mühendislik Tasarım Süreci temel alınarak geliştirdikleri ve yürütmeye çalıştıkları öğretim etkinliklerinin değerlendirilmesi ve yaşanabilecek aksaklıkların ortaya çıkarılması amaçlanmıştır. Özel durum yaklaşımı ile yürütülen çalışmada bulgular 2015-2016 eğitimöğretim döneminin bahar yarıyılında 45 öğretmen adayı ile yürütülmüştür. Bulgular öğretmen adaylarının geliştirdiği ve ürün haline getirmeye çalıştığ 45 etkinliğin araştırmacılar tarafindan belirlenen inceleme kriterlerine göre değerlendirilmesi ile elde edilmiştir. Geliştirilen ve ürün haline getirilmeye çalışılan etkinliklerde, ilk ve en önemli basamak olan problem tanımlama ve tanımlanan problemin anlaşılırlığı kısmında düşük nitelikte bir performans ile

*Yrd. Doç. Dr., İstanbul Aydın Üniversitesi, Eğitim Fakültesi, Email: aysegulkinik@aydin.edu.tr, ORCID ID:https://orcid.org/0000-0003-0947-5355

\begin{tabular}{lll}
\hline Gönderim:26.09.2017 & Kabul:08.11.2017 & Yayın:01.02.2018 \\
\hline
\end{tabular}


karşılaşılmıştır. Aynı şekilde problem belirleme basamağında yaşanan sıkıntılar nedeni ile yaratıcı çözüm üretme ve model haline getirme basamaklarında elde edilen performans düşük niteliktedir. Öğretmen adaylarının geliştirerek uygulamaya çalıştığı mühendislik tasarım temelli etkinliklerde, bireysel olarak yaşadıkları sıkıntılar göz önüne alındığında, gelişmelerin uygulayıcısı olacak öğretmen adaylarının yeni yöntem ve tekniklerden haberdar olarak yetiştirilmesi ve öğretmen yetiştirme programlarına mühendislik tasarım temelli fen öğretiminin dâhil edilmesi önerilmektedir.

Anahtar Kelimeler: Tasarım Temelli Fen Eğitimi; FeTeMM Eğitimi; İlkokul ve Ortaokul Mühendislik Uygulamaları

\section{Evaluation of The Elementary School Teacher Candidates' Engıneering Design Based \\ Science Instruction Activities}

Abstract: Science and Engineering Applications was added the science course curriculum so the number of subject areas was increased from 4 to 5.This field includes the strategies for delivering students to the level of innovation and invention, looking at interdisciplinary perspective to the problems, creation product using knowledge and skills, and how they can add value to these products by integrating science with mathematics, technology and engineering. Therefore, teachers who are expected to develop these skills and teachers' teaching activities should be improved. In this study, it is aimed to evaluate teaching activities developed and applied by classroom teacher candidates on the basis of Engineering Design Process in the scope of Science Teaching-II course of Istanbul Aydin University Faculty of Education and to reveal the troubles that may be experienced at school. This study is specific case study and based on document analysis. In this kind of research student experience, effects of a school reform or qualifications of an education program are examined. Special case studies can also be used to explain cause-effect relationship or to provide information to decision-making in 
some very complex cases. The sampling of the study is formed of 45 teacher candidates studying in 3rd class of Istanbul Aydin University Faculty of Educational Studies Classroom Teaching Department. Results were obtained by evaluation of 45 activities developed by teacher candidates by researchers according to determined examination criteria. In activities developed and tried to make a product a low level performance detected in problem description and intelligibility of described problem as the first and most important step. Likewise, due to problems and difficulties experienced in problem description step also performance in generating creative solutions and to make prototype is also low. Taking into account individual problems in engineering design based activities developed and applied by teacher candidates and considering importance of growing teacher candidates being informed about new methods and techniques it is recommended to include engineering design based science teaching to teacher education programs.

Keywords: Engineering Design Based Science Instruction, STEM Education, Primary Engineering Applications 


\section{Giriş}

Türkiye'nin inovasyon kapasitesini arttırabilmesi için yüksek nitelikli Fen, Teknoloji, Mühendislik ve Matematik (FeTeMM) işgücüne ihtiyacı vardır. Yirmi birinci yüzyılın değişen şart ve problemleriyle birlikte takım çalışması ve disiplinlerarası yaklaşımları doğuran bu ihtiyaç, gençlerimizi ve özellikle kız öğrencilerimizi erken yaşlardan itibaren FeTeMM araştırmaları yapabilecek şekilde eğitecek öğrenme ortamlarının tasarımını ve bu tasarımları etkin şekilde kullanabilecek öğretmenlerin yetiştirilmesini gerektirir. Buna mukabil yapılan araştırmalar göstermektedir ki, öğretmenlerimiz mesleklerine etkin bir FeTeMM eğitimi verebilmek için gerekli bütünleşik öğretmenlik bilgisinden yoksun şekilde başlamaktadır (Corlu, 2013).

Amerika Birleşik Devletleri, Avrupa ve Türkiye'de fen eğitiminin genel durumu üzerine çizilen çerçeve göstermektedir ki fen eğitimi için "araştırma-sorgulama" son derece önem taşımaktadır. Fakat yapılan çalışmalar ve raporalar incelendiğinde araştırmasorgulamaya dayalı öğrenme stratejisinin yarattı̆̆ eksikler göze çarpmaktadır (National Research Council [NRC], 2012). Bu strateji tek başına efektif insan gücünü yetiştirmede yetersiz kalmaktadır. Amerika gibi gelişmiş toplumlar, dünyadaki bu gelişmeler 1şı̆̆ında kendilerine aynayı tuttuklarında çok az sayıda vatandaşın araştırma-sorgulamaya dayalı öğrenme stratejisi ile geliştirilmeye çalışılan fen, matematik ve teknoloji alanlarında güçlü olduğunu ve birçoğunun ise bu alanlarda temel bilgi düzeyinde bile eksik olduğunu fark etmişlerdir. Bu nedenle anaokulundan on ikinci sınıfa kadar düzeyde fen eğitiminde yeni bir yaklaşım için geniş bir çağrı oluşturmuştur (National Academy of Engineering [NAE] ve NRC, 2009; Next Generations Science Standards [NGSS] , 2013; NRC, 2012). 
Brophy, Klein, Portsmore ve Rogers (2008) de vurguladığı gibi bu çağrı fen-teknolojimühendislik ve matematik alanlarının toplumsal açıdan önemli yönlerini içeren ve özellikle bir disiplin olarak mühendislik ışığında bir fen eğitimi çağrısıdır. Anaokulundan on ikinci sınıfa kadar fen eğitiminin öğrencilere fen, mühendislik ve teknoloji alanlarında beklenen başarıyı getirmesi bilimsel ve teknolojik bilgilerin günlük yaşamları ile ilişkili hale getirilmesi ve öğrencilerin devam edeceği meslek önemsenmeksizin fen, mühendislik ve teknoloji alanlarında temel becerilere sahip olması gündeme gelmiştir (NGSS, 2013; NRC, 2012). Roehrig, Moore, Wang ve Park (2012) belirttiği gibi mühendislik tasarımı temelinde bir fen eğitimi ile kastedilen fen-teknoloji-mühendislik ve matematik alanlarına yönlendirilecek bir neslin gelişimi değil bu alanlarda tüm toplumun okuryazarlığının geliştirilmesinin gerekli görülmesidir. Nitekim günümüzde yapılan araştırmalar da teknoloji, fen, mühendislik ve matematik gibi birçok disiplini içeren fen eğitiminde, y1llardır desteklenen araştırmaya/sorgulamaya dayalı fen eğitiminin, mühendislik tasarım yaklaşımı ile zenginleştirilmesi gerekliliğini ortaya koymuştur. Mühendislik tasarım temelli fen eğitimi öğrencilere gerçek yaşam bağlamı üzerinden deneyimler yaşayarak karar verme sürecine benzer aşamaları kullanma imkânı tanır niteliktedir ki bu durum ülkemizde fen bilimleri dersi kapsamında karar verme becerisinin geliştirilmesi yönündeki beklentiyi de desteklemektedir. Bilimsel araştırma-sorgulama ve mühendislik tasarımının kombinasyonu olarak değerlendirilebilecek tasarım temelli fen eğitimi ile öğrenciler, fene yönelik kuramsal bilgileri, karşılaştıkları tasarım problemlerini çözüme kavuşturmak için uygulamada kullanma firsatı yakalamaktadır. Bu durum okulda öğrenilenler ile gerçek yaşam arasında bağlantı kurulmasına hizmet etmekte ve fene yönelik anlamlı öğrenmenin gerçekleşmesine olanak tanımaktadır. Mühendislik tasarım temelli fen eğitimi, bilimsel araştırma-sorgulama ile tasarım geliştirme boyutlarının birleştirilmesini sağlar, bu süreçte öğrenciler bilginin nasıl elde edildiğini ve 
gerçek dünya problemlerinin nasıl çözüldüğünü deneyimleyerek, bilimsel okuryazarlık ve teknoloji okuryazarlığı gibi becerileri geliştirme olanağı bulurlar (Duschl, Schweingruber ve Shouse, 2007; Felix, 2010; NAE ve NRC, 2009; Pearson ve Young, 2002).

Türkiye'nin 2023 Vizyonu ve Milli Eğitim Bakanlığı (MEB) stratejik belgelerinin ortaya koyduğu amaçlar da fen-teknoloji-mühendislik-matematik eğitiminin ülkemiz ölçeğinde tanımlanmasının gerekliliğini ortaya koymaktadır (Çorlu, Adıgüzel, Ayar, Çorlu ve Özel, 2012). Fen eğitimi açısından bakıldığında ülkemizde, fen-mühendislik-teknoloji bağlamında, mühendislik uygulamaları ile destekli fen eğitimi araştırmaları henüz çalışılmaya başlamıştır (Bozkurt, 2014; Çavaş, Bulut, Holbrook ve Rannikmae, 2013; Çorlu vd., 2012; Çorlu, 2014; Ercan, 2014; Marulcu ve Sungur, 2012). ABD'de fen standartlarının mühendislik tasarım yaklaşımı ile zenginleştirilerek revize edilmesi sürecinden önce ülkenin birçok eyaletinde araştırmalar yapılarak bu noktaya gelinmiş olması ancak ülkemizde henüz bu yönde çok az sayıda çalışmaya rastlanmış olması ülkemiz ölçeğinde fen eğitiminde fen-teknolojimühendislik ilişkili araştırmaların yapılması gerektiğinin dikkate değer bir göstergesidir. Nitekim fen-teknoloji-mühendislik ve matematik eğitimi, inovasyon kabiliyetine sahip bir nesil yetiştirmek amacı güden reformların merkezinde yer almaktadır bu doğrultuda bu yaklaşımın kapsam, teori ve pratiği, okul ve üniversite düzeyinde irdelenmelidir (Çorlu vd., 2012).

\section{Mühendislik Tasarım Temelli Fen Bilimleri Eğitimi}

İlkokul düzeyi için önerilen (Şekil 1)'deki döngüde ortada mühendislik tasarım süreci basamakları yer almaktadır. Bu süreç, "Bir mühendis nasıl tasarım yapar?” sorusunun cevabı olarak düşünülebilir. Söz konusu süreç problemin belirlenmesiyle başlar, olası çözümler araştırılır ve bu çözümler arasından problemin özelliklerine göre en uygun olanı seçilir, çözüme yönelik bir prototip yapılır ve test edilir, çalışmazsa revize edilir ya da tekrar yapılır. Elbette ki mühendisler için süreç her zaman bu kadar sade olmayabilir ancak, burada yer verilen süreç 
ilkokul düzeyinde basitleştirilmiş olarak düşünülebilir. Bu döngü, fen bilimleri dersi boyunca da mühendislerin tasarım süresince gerçekleştirdikleri işlemlerin dikkate alınacağına işaret etmektedir. Bir ünite boyunca döngünün derse nasıl uyarlanacağı ise merkezin etrafındaki döngüde anlatılmaktadır. İlk olarak ünitede yer alan büyük tasarım görevi açıklanır. Bu aşama mühendislik tasarım sürecinde problemin belirlenmesine karşılık gelmektedir. Öğrencilerin büyük tasarım görevini gerçekleştirmek için küçük araştırma ya da küçük tasarımlar yoluyla gerekli bilgi ve becerileri edinme süreçleri planlanır. Öğrencilerin gerekli bilgi ve becerilere sahip olma sürecinden sonra büyük tasarıma yönelik öneriler geliştirilir. Büyük tasarım görevinden beklenen duruma göre en uygun öneriyi belirleyecekleri bu aşama, mühendislik tasarım sürecindeki olası çözümlerin araştırılması ve en uygun çözümün seçilmesi olarak tanımlanmaktadır. Bir sonraki aşamada öğrenciler büyük tasarım görevi için önerdikleri çözüm önerilerini ortaya koyacak bir model oluşturacaktır, bu aşama ise mühendislik tasarım sürecinde modelin yapılmasına denk gelmektedir. En son olarak öğrenciler tasarım çözümlerine yönelik modellerini test edecek ve eksiklikleri doğrultusunda modellerini güncelleyeceklerdir bu aşama mühendislik tasarım sürecinin son aşaması olan modelin test edilmesi aşaması ola

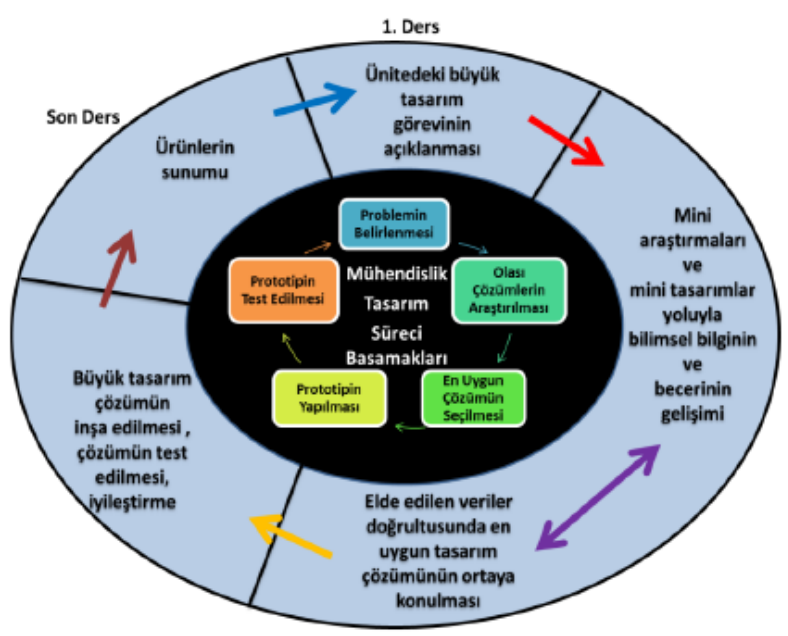


Şekil 1: Mühendislik tasarım süreci basamakları ekseninde yapılandırılan fen eğitimi

(Barnett, Connolly, Jarvin, Marulcu, Rogers, Wendell ve Wright, 2008; Ercan, 2013; Wendell, Connolly, Wright, Jarvin, Rogers, Barnett ve Marulcu, 2010)

Kolodner, Crismond, Gray, Holbrook ve Puntambekar'in (1998) tasarım yoluyla öğrenme yaklaşımının esas alındığı ve diğer yaklaşımlar ile desteklenerek oluşturulan bu döngüde, bilimsel araştırma-sorgulama ve tasarım düzlemi bağlamında tasarımların büyük oranda bilimsel araştırma sorgulamayı destekleyecek şekilde planlandığı söylenebilir (Wendell vd., 2010).

Bu çalışmada, Hynes, Portsmore, Dare, Milto, Rogers, Hammer ve Carberry’nin (2011) çalışması yol gösterici olmuştur. Wendell vd.'nin (2010) mühendislik tasarım sürecine yönelik belirlediği beş aşamadan oluşan sürecin, Hynes vd.'nin (2011) liseler için mühendislik tasarım yaklaşımının FeTeMM derslerine uyarlanmasına yönelik çalışmasında basamakların daha ayrıntılandırılarak 9 aşamadan oluştuğu görülmektedir. Hynes vd.'nin (2011) önerdiği 9 aşamadan oluşan mühendislik tasarım süreci döngüsü Şekil 2'de yer almaktadır.

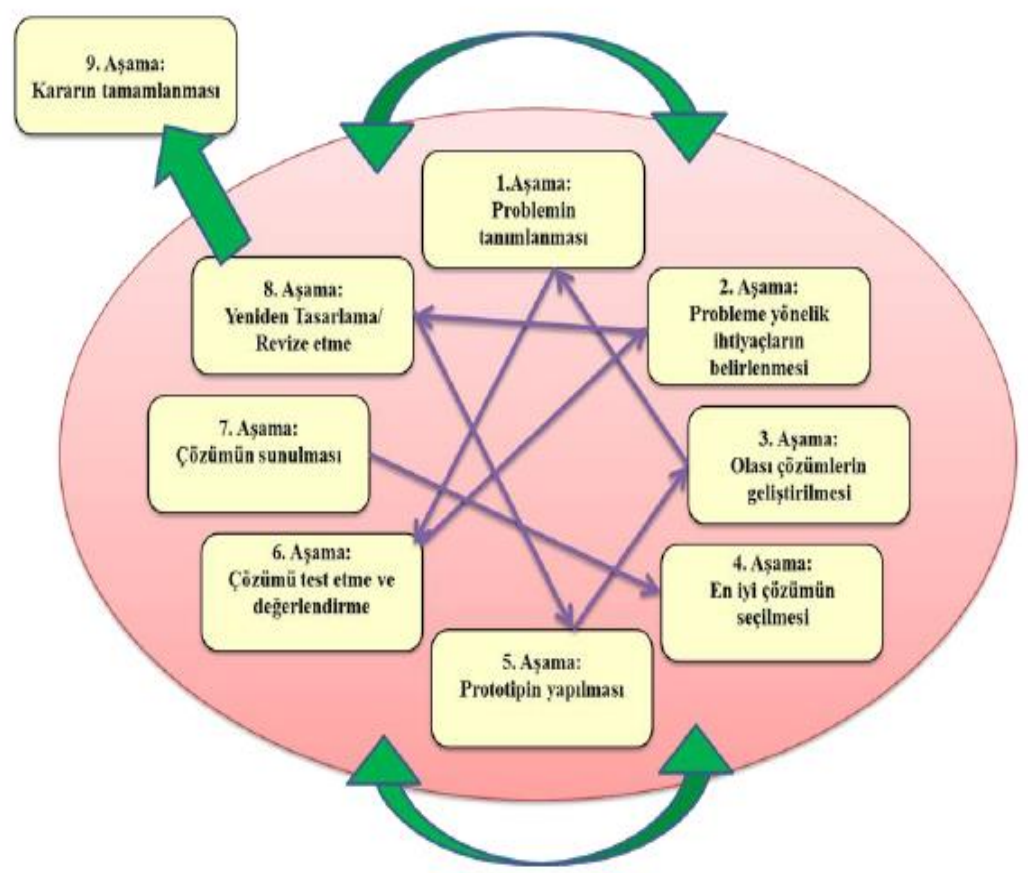

193 
Şekil 2: Mühendislik tasarım süreci (Hynes vd., 2011)

\section{Çalışmanın Amacı}

İstanbul Aydın Üniversitesi Eğitim Fakültesi Sınıf Öğretmenliği programında verilen Fen ve Teknoloji Öğretimi-II dersi kapsamında, öğretmen adaylarına mühendislik tasarım süreci odaklı eğitimler verilmiştir. Verilen eğitim kapsamında FeTeMM kavramı irdelenmiş ve mühendislik tasarım temelli öğretim etkinlikleri geliştirilmiştir. Bu kapsamda çalışmanın amacı, öğretmen adaylarının Mühendislik Tasarım Süreci temel alınarak geliştirdikleri ve yürütmeye çalıştıkları öğretim etkinliklerinin değerlendirilmesi ve bu süreç içerisinde yaşadıkları aksaklıkların ortaya çıkarılmasıdır.

\section{Yöntem}

Çalışmanın Deseni: Yapılan bu araştırmada da, öğrencilerin geliştirmiş oldukları çalışmalar belirlenen mühendislik tasarım temelli öğretim etkinlikleri değerlendirme ölçütlerine göre puanlandırılmış ve bu tür ödevlerin hangi basamaklarında sorunlar yaşandığ 1 değerlendirilmiştir. Bu kapsamda yapılan araştırma, bir özel durum çalışması olup doküman analizine dayanmaktadır. Durum Araştırması ile bir grup insan, konu, sorun veya programın yakından incelemesi yapılmaktadır. Bu araştırmalar öğrenci deneyimleri, bir okul reformunun etkileri yâda bir eğitim programının niteliklerini araştırabilir.

Çalışma Grubu: Araştırmanın çalışma grubunu, İstanbul Aydın Üniversitesi Eğitim Fakültesi Sınıf Öğretmenliği bölümünde öğrenim gören 3. sınıf 45 öğretmen adayı oluşturmaktadır. 
Veri Toplama Aracı ve Uygulama: Araştırmacılar tarafından, mühendislik tasarım temelli öğretim etkinliklerinde bulunması gereken ölçütler konusunda literatür taraması yapılmış ve mühendislik tasarım temelli öğretim etkinlikleri 10 maddelik değerlendirme rubriği geliştirilmiş ve (Tablo 1)'de sunulmuştur. Geliştirilen analitik rubrik alan uzmanı beş kişinin görüşü alınarak son haline getirilmiş ve geçerliliği tamamlanmıştır. Bilindiği üzere analitik rubrikte puanlama, ortaya konulan performansın parçalara bölünerek her bir parçanın puanlanması ve bu puanlardan da toplam puan elde edilmesi esasına dayanmaktadır. Analitik rubrik öğrencilerden ortaya koymaları istenen performansın ayrıntılı olarak tanımlanabildiği durumlarda kullanılabilir. Bu nedenle geliştirilen etkinlik değerlendirme ölçütleri beş aşamaya ayrılmış, maddeler "yapılan uygulamalar ilgisiz-yetersiz" (1), "yapılan uygulamalar kötüsınırlı-net değil” (2), "yapılan uygulamalar orta-geliştirilmeli” (3), "yapılan uygulamalar iyibaşarılı" (4), "yapılan uygulamalar çok iyi-mükemmel-istenilen tüm niteliklere sahip" (5) şeklinde puanlandırılmış ve böylece geliştirilen etkinliklerin mühendislik tasarım öğretim sürecine uygunluğunun ne derece sağlandığı değerlendirilmiştir. Ölçme sonuçlarının güvenilir olması için öğrenci etkinlikleri beş araştırmacı tarafından ayrı ayrı puanlandırılmış ve ortalamaları esas alınmıştır. Her bir maddeye ilişkin ortalama puanlar hesaplanarak tablo halinde sunulmuş ve aritmetik ortalamaları alınarak, 1,00-1,79: “Kötü”, 1,80-2,59: “Düşük nitelikte", 2,60-3,39: "Yeterli", 3,40-4,19: "İyi" ve 4,20-5,00: "Mükemmel” olarak değerlendirilmiştir. 3,40 ve yukarı ortalama puan alan maddeler başarılı olarak kabul edilmiş, 3,40'dan aşağı puan alan maddeler ise üzerinde daha fazla çalışılması gerektiği yönünde yorumlanmıştır.

Sınıf Öğretmenliği öğretmen adaylarına uygulanan Fen ve Teknoloji Öğretimi II dersi kapsamında üç hafta boyunca dokuz saatlik eğitim verilmiştir. Verilen eğitim kapsamında FeTeMM kavramı irdelenmiş, bu alanda geliştirilen mühendislik tasarım temelli öğretim 
etkinlikleri incelenmiş ve Fen Bilimleri öğretim programı kazanımlarına uygun olarak belirlenen bir konuda (Madde ve Değişim) grup çalışmaları yapılarak, sınıf içi mühendislik tasarım temelli öğretim etkinlikleri geliştirilmiştir. Ders kapsamında ikinci ve son adım olarak her bir öğrenciye, Fen Bilimleri dersi 3-5. sınıf öğretim programından sırasıyla farklı üniteler dağıtılarak, her öğrenciden mühendislik tasarım temelli öğretim etkinliği geliştirmesi ve geliştirmiş olduğu çalışmaya yönelik uygulama yapması istenmiştir.

Ödevler, araştırmacılar tarafından belirlenen mühendislik tasarım temelli öğretim etkinlikleri değerlendirme ölçütlerine göre puanlandırılmıştır. Böylece ödevlerin hangi basamaklarda sorunlar yaşandığı değerlendirilmiştir. Ek 1'de, bundan sonraki yapılacak çalışmalara yardımcı olması için öğrencilerin geliştirdikleri etkinliklerden kesitlere yer verilmiştir.

\section{Tablo 1}

Mühendislik Tasarım Temelli Öğretim Etkinliklerini Değerlendirme Rubriği

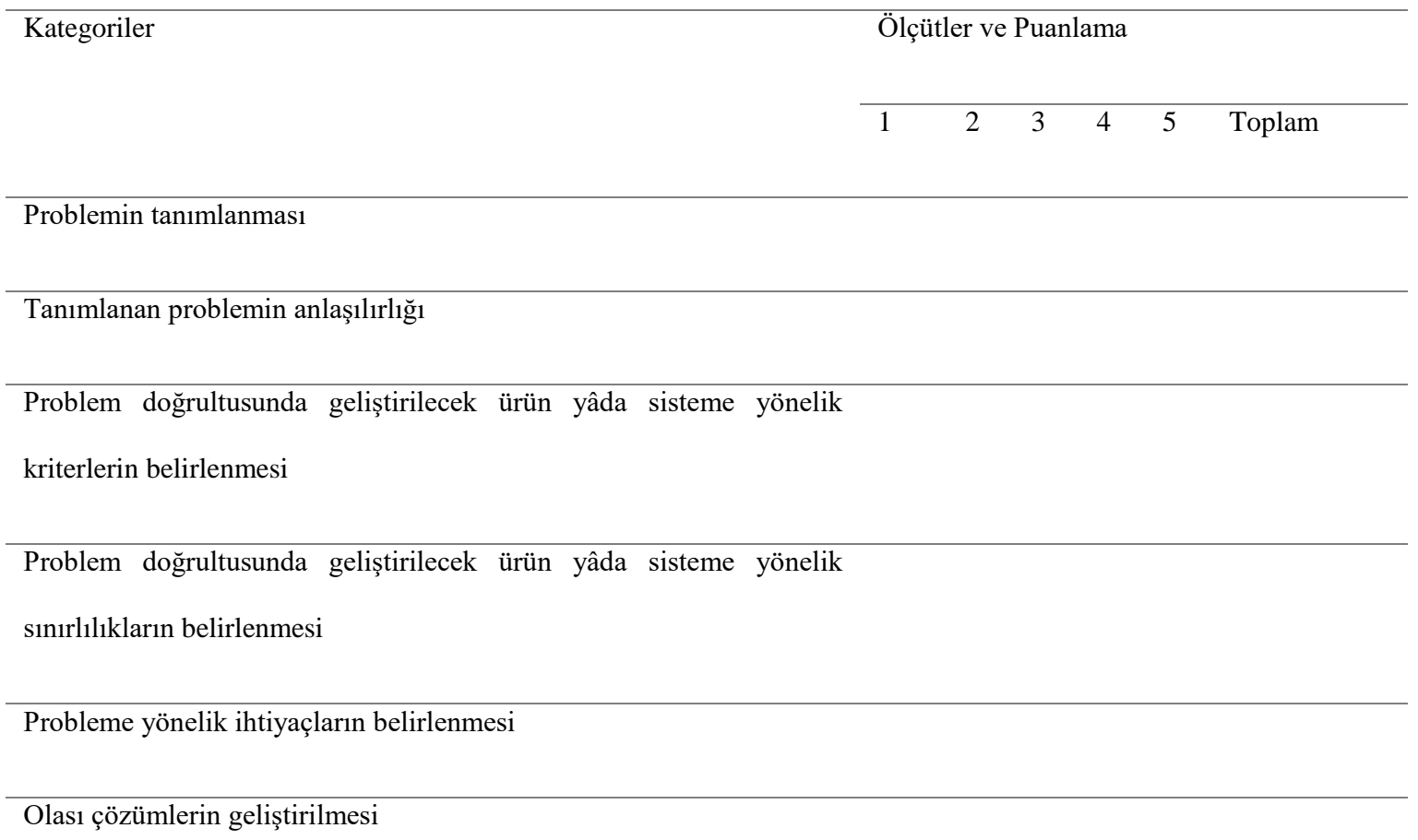


Çözümlerin yaratıcı ve uygulanabilir olması

Karar verme matrislerinin oluşturulması

Prototipin yapılması veya çizilmesi

Çözümün sunulabilecek aşamaya getirilmesi

Verilerin Analizi: Ölçme sonuçlarının güvenilir olması için öğrenci etkinlikleri beş araştırmacı tarafından ayrı ayrı puanlandırılmış ve ortalamaları esas alınmıştır. Her bir maddeye ilişkin ortalama puanlar hesaplanarak tablo halinde sunulmuş ve aritmetik ortalamaları alınarak, 1,00-1,79: “Kötü”, 1,80-2,59: "Düşük nitelikte”, 2,60-3,39: "Yeterli”, 3,40-4,19: "İyi” ve 4,20-5,00: "Mükemmel” olarak değerlendirilmiştir. 3,40 ve yukarı ortalama puan alan maddeler başarılı olarak kabul edilmiş, 3,40'dan aşağı puan alan maddeler ise üzerinde daha fazla çalışılması gerektiği yönünde yorumlanmıştır.

\section{Bulgular ve Yorum}

Çalışmanın verileri örneklemin geliştirdiği 45 adet etkinliği kriterlere göre incelenip puanlandırılmış nicel analizinden oluşmaktadır. Sınıf Öğretmenliği öğretmen adaylarının geliştirmiş oldukları ders etkinliklerinin değerlendirme ölçütlerine göre aldıkları puanların frekansları, yüzdeleri ve aritmetik ortalamaları Tablo 2'de verilmiştir.

\section{Tablo 2}

Ödevlerin Değerlendirme Kriterlerine Göre Aldıkları Puanlara İlişkin Frekans, Yüzde ve Aritmetik Ortalamaları 


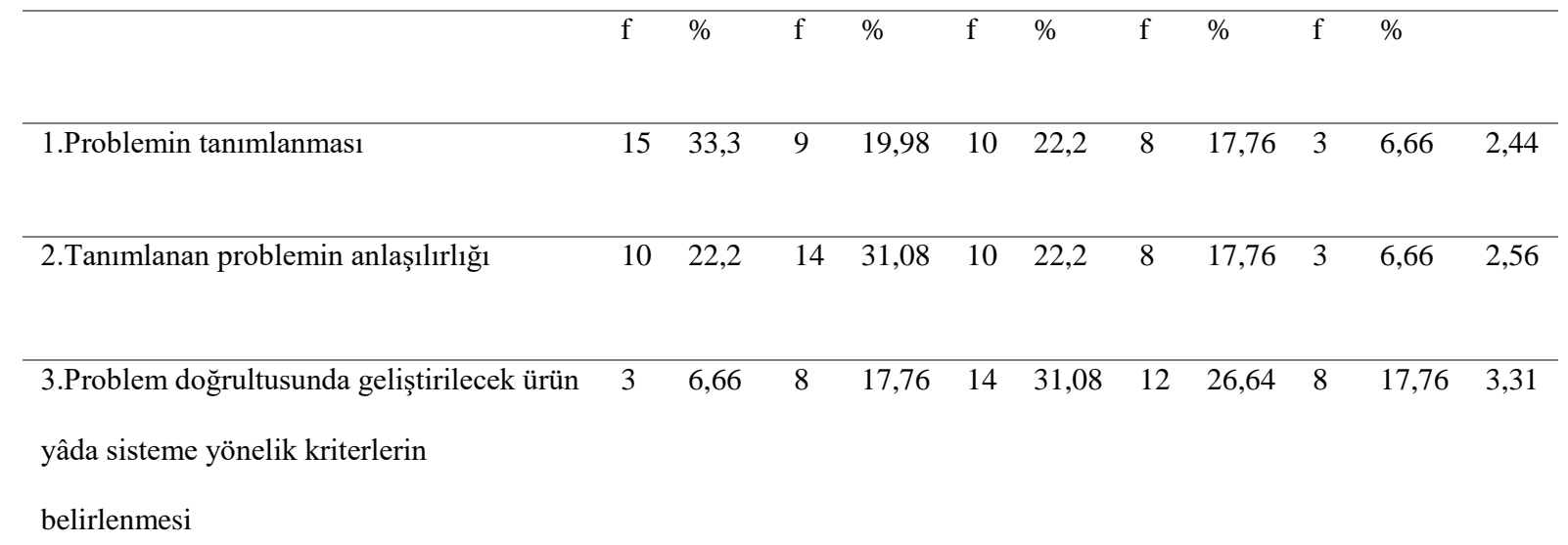

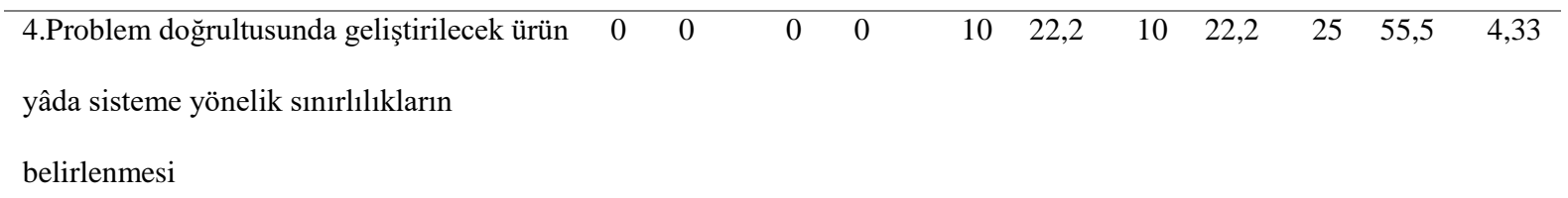

Tablo 2'de bulunan ortalamalar incelendiğinde ortalaması 1,00-1,79 puan aralığına düşen maddeler bulunmadığg görülmektedir. Bu durum sevindirici bir durumdur. Öğretmen adayları, yeni karşılaştıkları bir öğretim stratejisi karşısında farkındalık geliştirmiş ve bu durumu 
yaptıkları çalışmalara yansıtabilmişlerdir. Bu durum yine de diğer ortalamalar incelendiğinde tam olarak yeterli değildir. Öğretmen adaylarının yapılan çalışmalarda "kötü” olmasalar da, “mükemmel” seviyeyi yakalamaları da bir o kadar zor gözükmektedir. Bu durum farklı şekillerde yorumlanabilir ama en önemli nedenler arasında; öğretmen adaylarının bilgi birikimleri ve bugüne kadar rol model olmuş kişilerin kullandığı yöntem ve tekniklerin yetersizliği gösterilebilir. Öğretmen adayları yapılandırmacı kurama uygun, öğrenci merkezli ve yaratıcı süreçlere adapte olmakta zorlanmaktadırlar.

Ortalaması 1,80-2,59 puan aralığına düşen maddeler 1, 2, 7 ve 9. maddeler olarak tespit edilmiştir. Bu durum öğrencilerin bu basamaklarda "düşük nitelikte" bir performans ortaya çıkardığını göstermektedir. 1. ve 2. maddeler, öğretmen adaylarının çalışmaları için bulmaları gereken problemin açık ve anlaşılırlığı ile ilgilidir. Mühendislik tasarım süreci için problemin anlaşılması ve açık olması önemlidir, nitekim iyi tanımlanmamış problemler için çözümlerin ortaya konulması zor olmaktadır. Einstein'in dediği gibi "Problemin tanımlanması, çoğu kez çözülmesinden daha önemlidir”. Öğretmen adaylarının problem belirlemede düşük nitelikte performans göstermelerinin sebepleri arasında, adayların fikir kaynaklarının kısıtlı kalması gösterilebilir. Öğretmen adaylarının günlük hayatta karşılaştıkları veya gözlemledikleri sorunları zihinlerinde detaylandıramamaları, kendi uygulamalarında karşılaştıkları sorunların ve yaptıkları araştırmaların yetersizliği araştırma problemi tanımlanması aşamasında ortaya çıkmaktadır. Öğretmen adaylarının farklı alanlarda kazanmış olmaları gereken becerilerdeki eksikler, geliştirmeye çalıştıkları etkinliklerde ortaya çıkmaktadır. 7. ve 9. madde de bu durumu destekler niteliktedir. Öğretmen adayları problem bulmada zorlandıkları için, geliştirmiş oldukları çözümler de yaratıcılık ve uygulanabilirlikten uzak kalmaktadır. Çözümleri, ürettikleri problem ile ilgili olarak uyumsuz olduğu için prototip yapmakta da zorlanmışlar ve uygulanabilir çözümlerden uzaklaşmışlardır. 
3., 5., 6., 8., ve 10. maddelerin puan ortalaması 2,60-3,39 aralığında tespit edilmiştir. Belirtilen maddelerde yazan değerlendirme kriterleri “yeterli” olarak görülmektedir. Bu durum yeterli olarak gözüküyor olsa bile maddeler kendi içerisinde incelendiğinde farklı şekillerde yorumlanabilmektedir.

3. madde, problem doğrultusunda geliştirilecek ürün yâda sisteme yönelik kriterlerin belirlenmesi süreci ile ilgilidir. Etkinliklere verilen puanlar incelendiğinde, öğretmen adaylarının \%31,08'inin geliştirdikleri çalışmada kriterleri orta düzeyde, \%26,64'i iyi düzeyde, \%17,76’s1 ise mükemmel düzeyde belirlediği görülmektedir. Puanlar incelendiğinde kriter belirlemede eksikleri fazla olan öğretmen adaylarına da rastlanmaktadır. Problem doğrultusunda geliştirilecek ürün veya sisteme yönelik belirlenmesi gereken kriterlerde, öğretmen adaylarının yeterli düzeyde çıkması düşündürücü bir durumdur. Öğretmen adayları yeterli veya yetersiz olarak belirledikleri problem durumları karşısında özellik belirlemede fazla zorlanmamışlar yaptıkları ilk tespitler doğrultusunda kriterleri daha rahat belirleyebilmişlerdir. Fakat bu FeTeMM becerilerinin gelişebilmesi için yeterli bir durum değildir.

5. madde, problem durumuna yönelik ihtiyaçların belirlenmesi ile ilgilidir. Öğrencilerden, problem kapsamındaki ürün ya da sistem tasarımına yönelik birçok şey düşünülebilmeleri ve sorunu tamamen belirlemek için ihtiyaca yönelik araştırmalar yapmanın önemli olduğunu anlamaları beklenmiştir. Öğretmen adayları bu basamakta da yeterli düzeyde gözükmektedirler. Problem durumlarının çözümüne yönelik hangi bilgi kaynaklarına ihtiyaç duyabildiklerini daha rahat ifade edebilmişlerdir. Öğretmen adaylarının buradaki tek sıkıntısı sınırlı bilgi kaynaklarına erişim sağlamak istemeleridir. Problem durumunun çözümüne yönelik, sadece internet kaynaklı araştırmalar akıllarına gelmektedir. Problem durumu ile ilgili meslek dalları, ARGE birimleri, Teknoloji Merkezleri akıllarına gelmemektedir. Bu durumun 
değişmesi yönünde örnekler sınıfta verildiğinde ise, daha efektif ihtiyaçlar belirleyebilmektedirler.

6. madde olası çözümlerin geliştirilmesi ile alakalıdır. Öğretmen adayları bu madde de ne kadar yeterli düzeyde gözüküyor olsa da, sınıfın \%11,1'i kötü \%39,96's1 ise yetersiz düzeyde gözükmektedir. Yani sınıfın neredeyse yarısı belirlenen bu madde de beklenen düzeyin altında kalmıştır. Öğretmen adaylarının problem belirlemede yaşadıkları sıkıntılar bu basamakta da tekrar ortaya çıkmaktadır. Burada ki tek önemli nokta, öğretmen adayları herhangi bir problem durumuna karşı iyi veya kötü bir çözüm belirleyebilmeleridir. Bu nedenle düzey "yeterli” olarak görülmektedir. Fakat çözümlerin yaratıcı olma kısmında "düşük nitelikte” gözükmektedirler. Bu durum irdelenmesi gereken bir durumdur.

8. madde öğretmen adayların ders sırasında yapımını öğrendikleri matrisler ile ilgilidir. Öğrencilerin çözümleri içinden en iyisini seçmeleri beklenen bu aşama, onların hem kriterlerin en çoğunu karşılayan hem de sınırlıkların en çok karşılandığı çözüme yönelmelerini gerektirmektedir. Öğretmen adayları karar matrisleri oluşturma düzeyinde “yeterli” düzeyde gözükmektedir. Öğrenilmiş ve sistematik bir yol izlenen matrislerin yapımı, öğretmen adaylarını o kadar fazla zorlamamıştır.

10. madde geliştirmiş oldukları çözümlerin sunumu ile alakalıdır. Öğretmen adayları, bu aşamada "yeterli” düzeyde gözükmektedir. Buradaki tek sıkıntı sunum denilince, öğretmen adaylarının aklına sadece Office programlarının gelmesidir. Yaratıcı ve mükemmel düzeyde sunum yapan hiçbir adaya rastlanmamıştır.

Ortalaması 3,40-4,19 puan aralığına düşen maddelere, yapılan çalışmada rastlanmamıştır. 
Ortalaması 4,20-5,00 puan aralığın düşen tek bir maddeye rastlanmıştır. 4. Madde yani problem doğrultusunda geliştirilecek ürün yâda sisteme yönelik sinırlılıkların belirlenmesi kısmında, öğretmen adayları beklenenin dışı "mükemmel" düzeyde bir performans göstermişlerdir. Öğretmen adayları, çözüme ulaşmayı engelleyecek tüm engelleri çok güzel listeleyebilmişlerdir. Burada beklenen bu engelli aşıp, en etkin çözüme ulaşmalarıdır. Fakat yapılan çalışmada, engelleri belirlemekte çok iyi olan öğretmen adaylarının bu engeller yüzünden yaratıcı çözümlere ulaşamadığıdır.

\section{Tartışma}

Fen Bilimleri Öğretimi dersi içerisinde yapılan uygulamaların bir ürünü olarak, öğretmen adaylarından istenilen mühendislik tasarım temelli öğretim etkinliklerinin değerlendirmesi incelendiğinde, öğretmen adaylarının beklenenin altında bir performans gösterdikleri görülmektedir. Özellikle etkinlik geliştirirken izlenmesi gereken adımlar detaylı incelendiğinde, öğretmen adaylarının yaşadıkları sıkıntılar, alışkanlıkları, yeni bilgi karşısındaki dirençleri ve farkındalıkları rahat bir biçimde fark edilebilmektedir.

Öğretmen adaylarının tasarım, mühendislik ve teknolojiyi öğretmek konusunda izlemeleri gereken adımlarda yaşadıkları sıkıntılar, geliştirip uygulamaya çalıştıkları çalışmalarda çok rahat görülebilmektedir. Öğretmen adayları aldıkları eğitim içeriğine rağmen, uygulama yapabilmek için etkinlik geliştirmeye çalışırken çok zorlanmaktadırlar. Bu durum, bu zamana kadar geleneksel bir anlayışla yetişmelerinden kaynaklanıyor olabilir. Öğretmen adayları, kendilerini yeni yöntem ve teknikleri uygulayabilmek için olumlu motive etmeye çalışsa bile, süreç içerisindeki bilgi birikimleri ve örnek modelleri yetersiz kaldığı için bir süre sonra uygulamaları yanlış yapabilmektedirler. $\mathrm{Bu}$ durum öğretmen adaylarının kendilerini yetersiz ve güvensiz hissetmelerine neden olmaktadır. Öğretmenin FeTeMM öğretimi 
konusundaki güveni, FeTeMM ile ilgili içeriği öğretmek için önemli bir öngörü aracıdır (Ford, 2007; Jarrett, 1999). Literatürde yapılmış çalışmalar incelendiğinde, yapılan bu çalışmayı destekler nitelikte birçok sonuca rastlamaktayız. Yaşar, Beker, Robinson ve Roberts (2006) tarafından yapılan çalışmada, öğretmenlerin tasarım, mühendislik ve teknolojiyi öğretmek konusunda kendilerine güvenmediklerini ya da kendilerini yeterli hissetmediklerini ortaya konulmuştur. Arafah (2011) da araştırmasında öğretmenlerin mühendisliği, fen, teknoloji ve matematikle birleştirmek konusunda ilgilerinin artmasına karşın kendilerini yeterli hissetmediklerini tespit etmiştir. Hsu, Purzer ve Cardella (2011) ilkokul öğretmenlerinin tasarım, mühendislik ve teknoloji ile ilgili algılarını ve bu kavramlara yakınlığını araştırdıkları çalışmalarında öğretmen adaylarının mühendislik, teknoloji ve tasarımın önemli olduğuna inandıkları, ancak bu kavramları öğretmek konusunda kendilerini yeterli hissetmedikleri tespit edilmiştir. Harlen ve Holroyd (1997) yaptıkları çalışmada, FeTeMM eğitiminde öğretmenin kendine güvenmesinin önemini ortaya koymakta ve düşük öğretmen güveninin öğrenci öğrenimi üzerinde yarattığı olumsuz etkilerden bahsetmektedir. Ayrıca FeTeMM alanında öğretmenin hisettiği güvenin, bilgi ile pozitif korelasyon içerisinde olduğu bildirilmiştir

Kendine güvenen öğretmen adaylarının yetişebilmesi için, öğretim ve uygulama derslerinde geliştirilecek ve hayata geçirilecek etkinliklerle öğretmen yeterlilikleri arttırılabilir. Özelikle öğretmen veya öğretmen adayları ile yürütülebilecek ek ders çalışmaları, FeTeMM öğretimi için pozitif yönde bir etki yaratabilmektedir (Bleicher, 2006). Bu tür etkilerin yaratılabilmesi için öğretmen adayları ile birlikte farklı derslerde birbirini takip eden uygulamalar geliştirilip hayata geçirilebilir. Bu şekilde yapılan çalışmalarda süreklilik sağlayan ve içselleştiren öğretmen adayları süreç içerisinde daha başarılı çalışmalar ortaya çıkarabilecektir. Örneğin Capobianco (2011) öğretmenlerin mühendislik tasarım sürecini anlamalarını ve sınıf uygulamalarında kullanma yeterliği kazanma durumlarını inceledikleri 
araştırmalarında öğretmenlere eğitim vererek ardından sınıf uygulamalarını gözlemlemiş ve öğretmenlere mühendislik tasarım sürecini içeren ders planları hazırlatılıp bunları incelemiştir. Araştırmacı, öğretmenlerin mühendislik tasarım sürecini anlama ve etkinliklerde kullanma yeterliğinin geliştiğini tespit etmiştir. Araştırmanın bu sonucunu destekleyici başka bir araştırmada Copobianco (2013) mühendislik tasarım yaklaşımıyla fen öğretmek için pedagojik gereksinimleri karşılamak amacıyla hizmet öncesi ve hizmet içi öğretmenlere 2 haftalık yoğun eğitim programı uygulayarak öğretmenlerin mühendislik tasarım sürecini anlama ve sınıf uygulamalarında kullanma yeteneğinin geliştiğini tespit etmiştir. Söz konusu araştırmalar da göstermektedir ki öğretmenlerin ya da öğretmen adaylarının kendilerini mühendislik tasarım sürecini kullanabilmek için yeterli hissedebilmeleri eğitim programları ile mümkün olabilmektedir. Nadelson, Callahan, Pyke, Hay ve Matthew (2013) yaptıkları çalışmada, 33 ilkokul öğretmeni ile iki yıl boyunca FeTeMM eğitimi ile ilgili çalışmışlar ve sonrasında da, öğretmenlerin öğrencileri ile efektif ürünler ortaya koyabildiklerini tespit etmişlerdir.

Öğretmen adaylarının, mühendislik tasarım temelli öğretim etkinlikleri geliştirirken düşük performans gösterdikleri basamakların başında "problem belirleme”, "yaratıcı çözümler bulma”, “çözüm önerilerinin modelini yapma” gibi aşamaların geldiği görülmektedir. Bu aşamaların yanı sıra öğretmen adaylarının çözüme ulaşmak için sınırlı bilgi kaynaklarına başvurduğu da gözden kaçmamaktadır. Bu basamaklarda ortaya çıkarılan yetersizliklerin bilimsel süreç becerilerinin kazanılamaması ile ilişkisi olabilir. Bireylerin FeTeMM'i daha iyi anlamaları ve derslere entegre etmeleri kolaylaştırılması için her kademe düzeyinde (ilkokul, ortaokul, lisans...) yapılacak araştırma sorgulamaya dayalı çalışmalar, öğretmenlerin bir bilim insanı ve mühendis gibi düşünmeleri sağlanabilir (Gökbayrak ve Karışan, 2017). Sungur ve Marulcu (2014) tarafından fen bilgisi öğretmen adayları ile gerçekleştirilen bir çalışmada öğretmen adaylarına "mühendislik dizaynla temellendirilmiş bir ders öğrencilerin hangi 
becerilerini geliştirebilir?” sorusu yöneltilmiş ve öğretmen adaylarının verdikleri cevapların birçoğunun bilim insanlarında gelişmiş bulunan ve öğrencilere fen eğitimi ile kazandırılması hedeflenen bilimsel süreç becerileri ile örtüştüğü tespit edilmiştir. Araştırmacının bu tespiti, bu araştırmada öğretmen adaylarının bilimsel süreç becerilerinin mühendislik tasarım temelli fen etkinlikleri ile geliştirilmiş olmasını dolaylı olarak destekler niteliktedir. Bu nedenle bu tür süreçlere dâhil edilmek istenen öğretmen adaylarının ilk olarak bilimsel süreç becerileri tam olarak geliştirilmeli ve çalışmalara bu şekilde başlanmalıdır. Beklenen performans ancak bu şekilde üst düzeylere çıkarılabilir.

\section{Sonuç ve Öneriler}

Yapılan çalışmada, öğretmen adayları ile yapılan FeTeMM eğitimi sonrasında öğretmen adaylarının problem tanımlama, tanımlanan problemin net ve anlaşılır olma, tanımlanan probleme uygun geliştirilen çözüm önerilerinin yaratıcı ve uygulanabilir olma ve çözüm önerilerine uygun model geliştirme aşamasında "düşük nitelikte"; problem doğrultusunda geliştirilecek ürün yâda sisteme yönelik kriterlerin belirlenmesi, probleme yönelik ihtiyaçların belirlenmesi, olası çözümlerin geliştirilmesi, karar verme matrislerinin oluşturulması ve çözümün sunulabilecek aşamaya getirilmesi aşamasında "yeterli" problem doğrultusunda geliştirilecek ürün yâda sisteme yönelik sınırlılıklar belirlenmesi aşamasında "mükemmel” seviyesinde bir performans gösterdikleri görülmektedir. Elde edilen bu sonuçlar doğrultusunda aşağıdaki öneriler verilebilir:

Öğretmen adaylarının derslerdeki deneyimlerinin niteliğinden haberdar edilmeleri dersin amacına ulaşabilmesi açısından önemlidir. $\mathrm{Bu}$ nedenle öğretim ve uygulama derslerinde öğretmen adaylarına her konu için mümkün olduğu kadar fazla uygulama yaptırılmalı ve bu uygulamalara verilecek dönütler sayesinde eksiklikleri giderilmelidir. 
Öğretmen adayları geleneksel bir eğitim sonucu eğitim fakültelerine geldiklerinden yeni bir anlayış kazanmaları zor olabilmektedir. Bu nedenle çağdaş öğretim yaklaşımları özellikle öğretmen yetiştiren bölümlerde mümkün olduğunca alan eğitimi derslerine yansıtılmalıdır.

Öğretmen adaylarının mühendislik tasarım temelli öğretim etkinlikleri geliştirmeleri beklenmeden önce bilimsel süreç becerileri irdelenmeli ve öğretmen adaylarının temelbütünleştirilmiş süreç becerilerini kazanmaları için farklı alanlarda uygulamalar yapılmalıdır.

Öğretmen adaylarının öğretim dersleri süreci boyunca geliştirilen materyallerini sahada uygulamaları desteklenmeli ve öğretmen adaylarının yaşadıkları aksaklıkları gözlemleyerek geliştirdikleri etkinlikleri farklı yaş grubu öğrencilerine göre revize etmeleri sağlanmalıdır.

Öğretmen adaylarının mühendislik tasarım temelli fen etkinliklerinin çeşitlerini ve farklı uygulamalarını görmeleri için, Türkiye genelinde ücretsiz olarak düzenlenen FeTeMM etkinliklerine katılmaları özendirilmeli ve bu alanda yeni bilgiler edinmeleri sağlanmalıdır.

Öğretmen adaylarının farklı alanlarda gelişimini hızlandırabilmek için, bölüm genelinde disipliner çalışmalar yürütülmelidir. Öğretmen adaylarının fen ve matematik öğretimi derslerinde yürütecekleri ortak çalışmalar, yeni bir anlayış kazanmalarını kolaylaştıracaktır. 


\section{Makalenin Bilimdeki Konumu}

Eğitim Bilimleri Anabilim Dalı, Fen Bilimleri Anabilim Dalı

\section{Makalenin Bilimdeki Özgünlüğü}

Makaledeki bilgiler, öğretmen adaylarının ve öğretmenlerin Fen Bilimleri öğretim programı içerisindeki endişelerini ortaya çıkarabilecek niteliktedir.

Makaledeki bilgiler Fen Bilimleri öğretim programının eksiksiz yürütülebilmesi için öncesinde yapılması gerekenleri ortaya koymaktadır.

Makalede ortaya çıkan sonuçlar tüm öğretmenlerin yaşayabilecekleri sıkıntıları ortaya koyar niteliktedir. Bu nedenle erken önlem alınması konusunda yapılması gerekenleri ortaya koyar niteliktedir.

Makaledeki bilgiler Fen Bilimleri Öğretim programında yer alan FeTeMM uygulamalarında yaşanabilecek aksaklıkları ortaya çıkarabilecek niteliktedir. 


\section{Kaynaklar}

Arafah, M. M. (2011). But what does this have to do with science? Building the case for engineering in K-12. Master Thesis, Cleveland State University, United States.

Barnett, M. Connolly, K. G., Jarvin, L., Marulcu, I.Rogers, C., Wendell, K. B. \& Wright, C. G. (2008). Science through LEGO engineering design a people mover: simple machines. 10 Aralık 2015 tarihinde http://www.legoengineering.com/wpcontent/uploads/2013/05/Lecom_Complied_Packe t_Machines_LowRes.pdf sayfasından erişilmiştir.

Bleicher, R. E. (2006). Nurturing confidence in preservice elementary science teachers. Journal of Science Teacher Education, 17, 165-187.

Bozkurt, E. (2014). Mühendislik tasarım temelli fen ĕğitiminin fen bilgisi öğretmen adaylarının karar verme becerisi, bilimsel süreç becerileri ve sürece yönelik algılarına etkisi. Doktora Tezi, Gazi Üniversitesi Eğitim Bilimleri Enstitüsü, Ankara.

Brophy,S., Klein, S., Portsmore, M., \& Rogers, C. (2008). Advancing engineering education in P-12 classrooms. Journal of Engineering Education, 97(3), 369-387.

Capobianco, B. M. (2011). Exploring a science teacher's uncertainty with integrating engineering design: an action research study. Journal of Science Teacher Education, 22, 645-660.

Capobianco, B. M. (2013). Learning and teaching science through engineering design: insights and implications for professional development. Association for Science Teacher Education, Charleston, SC. 
Çavaş, B., Bulut, Ç., Holbrook, J., Rannikmae, M. (2013). Fen eğitimine mühendislik odaklı bir yaklaşım: ENGINEER projesi ve uygulamaları. Fen Bilimleri Öğretimi Dergisi, 1(1), $12-22$.

Çorlu, M. A., Adıgüzel, T., Ayar, M. C., Çorlu, M. S., Özel, S. (Haziran, 2012). Bilim, teknoloji, mühendislik ve matematik (BTMM) eğitimi: disiplinler arası çalışmalar ve etkileşimler. Sözel bildiri, X. Ulusal Fen Bilimleri ve Matematik Eğitimi Kongresi, Niğde Üniversitesi, Niğde.

Çorlu, S. (2014). Insights into stem education praxis: an assessment scheme for course syllabi. Educational Sciences: Theory \& Practice , 13(4), 2477-2485

Çorlu, S. (2013). FeTeMM eğitimi makale çağrı mektubu. Turkish Journal of Education, 3(1), 4-10

Duschl, R., Schweingruber, H., \& Shouse, A., (Edt.) (2007). Taking science to school: learning and teaching science in grades $K-8$. The National Academies Press, Washington DC

Ercan, S (2013). Mühendisliğin fen ĕgitimine entegrasyonu: Mü(fen)dislik. Sözel bildiri, Uluslararası Eğitimde Değişim ve Yeni Yönelimler Sempozyumu, Necmettin Erbakan Üniversitesi, Konya.

Ercan. S. (2014). Fen eğitiminde mühendislik uygulamalarının kullanımı: tasarım temelli fen eğitimi. Doktora Tezi, Marmara Üniversitesi Eğitim Bilimleri Enstitüsü, İstanbul.

Felix, A. L. (2010). Design-based science for STEM Student recruitment and teacher professional development. Mid-Atlantic ASEE Conference, Villanova University.

Ford, B. A. (2007). Teaching and learning: Novice teachers' descriptions of their confidence to teach science content. Doctoral dissertation, Available from ProQuest Dissertations and Theses database. 
Gökbayrak, S. ve Karışan, D. (2017). STEM etkinliklerinin fen bilgisi öğretmen adaylarının bilimsel süreç becerilerine etkisi, Batı Anadolu Ĕ̆itim Bilimleri Dergisi, 8(2), 63-84.

Harlen, W., \& Holroyd, C. (1997). Primary teachers' understanding of concepts of science: Impact on confidence and teaching. International Journal of Science Teaching, 19, 93105

Hsu, M-C., Purzer S. \& Cardella M.E., (2011). Elementary teachers' views about teaching design, engineering and technology. Journal of Pre-College Engineering Education Research,1(2),31-39.

Hynes, M., Portsmore, M., Dare, E., Milto, E., Rogers, C., Hammer, D. \& Carberry, A. (2011). Infusing engineering design into high school STEM courses. 10 Şubat 2016 tarihinde http://ncete.org/flash/pdfs/Infusing\%20Engineering\%20Hynes.pdf sayfasindan erişilmiştir.

Jarrett, O. S. (1999). Science interest and confidence among preservice elementary teachers. Journal of Elementary Science Education, 11, 47- 57.

Kolodner, J. L., Crismond, D., Gray, J., Holbrook, J. \& Puntambekar, S. (1998). Learning by Design from Theory to Practice. 6 Aralı 2015 tarihinde http://www.cc.gatech.edu/projects/lbd/htmlpubs/lbdtheorytoprac.html sayfasindan erişilmiştir.

Marulcu, İ. ve Sungur, K. (2012). Fen bilgisi öğretmen adaylarının mühendis ve mühendislik algılarının ve yöntem olarak mühendislik-dizayna bakış açılarının incelenmesi. Afyon Kocatepe Üniversitesi Fen Bilimleri Dergisi, 12 (2012), 13-23.

Nadelson, L.S., Callahan, J., Pyke, P., Hay, A., \& Schrader, C. (2009, June). A systemic solution: Elementary-teacher preparation in STEM expertise and engineering 
awareness. Proceedings of the American Society for Engineering Education Annual Conference \& Exhibition, Austin, TX.

National Research Council [NRC]. (2012). A Framework for k-12 science education: practices, crosscutting concepts, and core ideas. The National Academic Press, Washington DC National Academy of Engineering [NAE] \& National Research Council [NRC] (2009). Engineering in K-12 education understanding the status and improving the prospects. Edt. Katehi, L., Pearson, G. \& Feder, M. National Academies Press. Washington DC Next Generations Science Standards [NGGS]. (2013). The next generation science standardsexecutive summary. 11 Aralk 2015 tarihinde: http://www.nextgenscience.org/sites/ngss/files/Final\%20Release\%20NGSS\%20Front\% 20Matter\%20-\%206.17.13\%20Update_0.pdf sayfasından erişilmiştir.

Pearson, G., \& Young, A. T. (Ed.). (2002). Technically speaking: Why all Americans need to know more about technology. The National Academies Press, Washington DC

Roehrig, G.H., Moore, T.J., Wang, H.-H., \& Park, M.S. (2012). Is adding the E enough?: investigating the impact of K-12 engineering standards on the implementation of STEM integration. School Science and Mathematics, 112(1), 31-44.

Sungur Gül, K. \& Marulcu, İ. (2014). Yöntem olarak mühendislik-dizayna ve ders materyali olarak legolara öğretmen ile öğretmen adaylarının bakış açılarının incelenmesi. International Periodical for The Languages, Literature and History of Turkish or Turkic, 9(2), 761-786.

Yasar, S., Baker, D., Robinson-Kurpius, S., \& Roberts, C. (2006). Development of a survey to assess K-12 teachers' perceptions of engineers and familiarity with teaching design, engineering, and technology. Journal of Engineering Education, 205-216. 
Wendell, K. B., Connolly, K. G., Wright, C. G., Jarvin, L., Rogers, C., Barnett, M., \& Marulcu, I. (2010). Incorporating engineering design into elementary school science curricula. American Society for Engineering Education Annual Conference \& Exposition, Louisville, KY.

\section{Summary}

Problem Statement: : Engineering and design skills have been added in the new science curriculum. This field includes the strategies for delivering students to the level of innovation and invention, looking at interdisciplinary perspective to the problems, creation product using knowledge and skills, and how they can add value to these products by integrating science with mathematics, technology and engineering. Therefore, teachers who are expected to develop these skills and teachers' teaching activities should be improved. In this regard, the main problem of the study can be stated as follows: What are the difficulties in developed engıneerıng desıgn based science instruction actıvities?

Purpose of the Study: In this study, it is aimed to evaluate teaching activities developed and applied by classroom teacher candidates on the basis of Engineering Design Process in the scope of Science Teaching-II course of IAU Faculty of Education and to reveal the troubles that may be experienced at school. This study is specific case study and based on document analysis. In this kind of research student experience, effects of a school reform or qualifications of an education program are examined. Special case studies can also be used to explain causeeffect relationship or to provide information to decision-making in some very complex cases. Method(s): This study is specific case study and based on document analysis. In this kind of research student experience, effects of a school reform or qualifications of an education program are examined. Special case studies can also be used to explain cause-effect 
relationship or to provide information to decision-making in some very complex cases. The sampling of the study is formed of 45 teacher candidates studying in 3rd class of Istanbul Aydin University Faculty of Educational Studies Classroom Teaching Department. Nine-hour education course for three weeks were given to Classroom teacher candidates within the scope of Teaching of Science and Technology II course. STEM concept was elaborated within the scope of education provided, engineering design based educational activities developed in this area were examined and engineering design-based learning activities in the classroom have been developed through group works in a subject determined in accordance with Science curriculum learning gains (Matter and Change). As a second and final step in the scope of course, each student was given different units from Science lessons 3-5th classes and asked to develop engineering design based learning activities and to make applications for work developed by student.

Findings and Discussions: Literature was scanned by researchers about the criteria to be included in the engineering design based teaching and learning activities and assessment rubric of 10 aching techniques. Opinion of the five analytic rubrics experts were taken and finalized and validation has been completed. As it is known scoring in analytic rubrics is based on dividing parts of the performance and scoring each part and obtaining a total score of these points. Analytic rubrics can be used in situations where performance asked to students to perform can be described in detail. Therefore, activity evaluation criteria developed is divided into five phases, items are scored as "applications made are unrelated-insufficient" (1) " applications made are bad-limited-unclear" (2) " applications made are medium level and should be improved" (3) " applications made are good-successful" (4) " applications made are very good-excellent-having all required qualities "(5) and conformity of activities developed to engineering design teaching process is evaluated. For reliable measuring results student 
activities have been scored by five researchers separately and averages were taken as basis. Average scores for each item were calculated and presented in table and the arithmetic averages were found: 1.00 to 1.79 : "bad", 1.80 to 2.59: "Low ", 2.60 to 3.39: "Adequate" 3.40 to 4.19 " Good" and from 4.20 to 5.00 " Perfect". Items with average score of 3.40 and above have been considered successful and items with less than 3.40 were evaluated as should be studied further. Conclusions and Recommendations: Results were obtained by evaluation of 45 activities developed by teacher candidates by researchers according to determined examination criteria. In activities developed and tried to make a product a low level performance detected in problem description and intelligibility of described problem as the first and most important step. Likewise, due to problems and difficulties experienced in problem description step also performance in generating creative solutions and to make prototype is also low. Taking into account individual problems in engineering design based activities developed and applied by teacher candidates and considering importance of growing teacher candidates being informed about new methods and techniques it is recommended to include engineering design based science teaching to teacher education programs.

Keywords: Engineering Design Based Science Instruction, STEM Education, Primary Engineering Applications 


\section{Ek-1}

\section{Araç/Silecek Tasarımı}

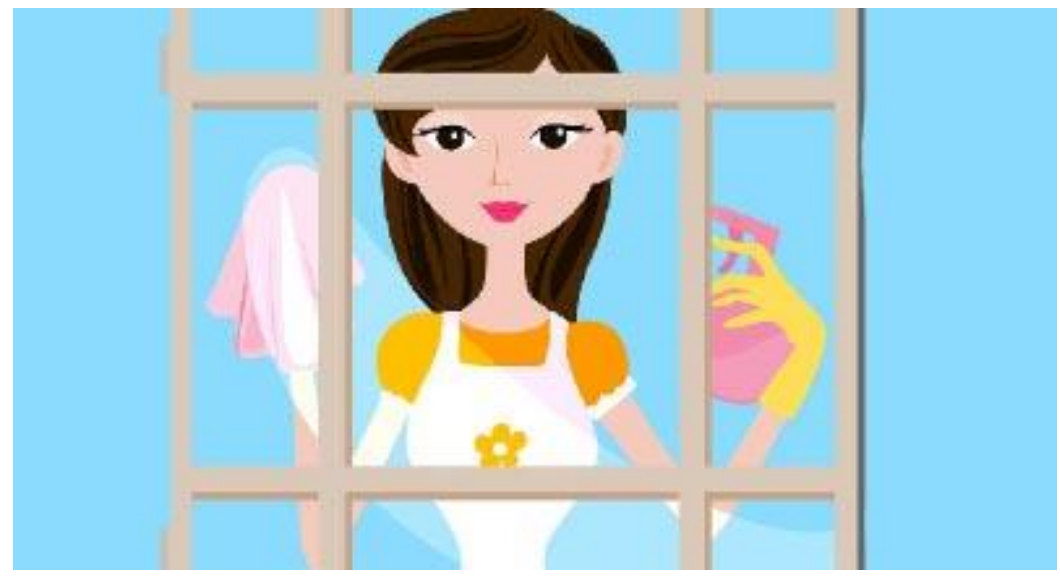

Problem Durumu: Pelin salonda yapbozu ile oynarken annesi de salonun camlarını silmektedir. Ancak Pelin'in annesi hamile olduğu için camları silmekte zorlanmaktadır. Bu durumu fark eden Pelin annesinin yorulmadan camları nasıl sileceğini düşünmeye başlar.

1. Pelin'in annesinin bu durumdan kurtulmasını sağlayacak çözüm/çözümler için özellikler neler olabilir?

2. Pelin'in annesinin bu durudan kurtulmasını sağlayacak çözüm/çözümler için sinırlılıklar neler olmalı? 
3. Pelin'in bu durumuna çözüm getirmek için sınıf ortamındaki kaynakları kullanarak araştırma yapabilirsiniz. Ancak öncelikle ne gibi bilgilere ihtiyacınız olduğunu grup arkadaşlarınızla tartışarak not ediniz.

4. Hangi kaynakları kullandınız? Nedenleri ile açıklar mısınız?

5. Pelin'in annesinin durumu için önerdiğiniz çözüm önerileri nelerdir?

6. Çözüm önerilerinizden birine karar vermeniz için her bir çözümü kriterleriniz ve sınırlılıklarınız bağlamında sorgulamanızı bekliyoruz. Mühendisler çözüm önerilerini sorgulamak için geçirdikleri bu sorgulama sürecinde karar verme matrislerinden yararlanırlar.

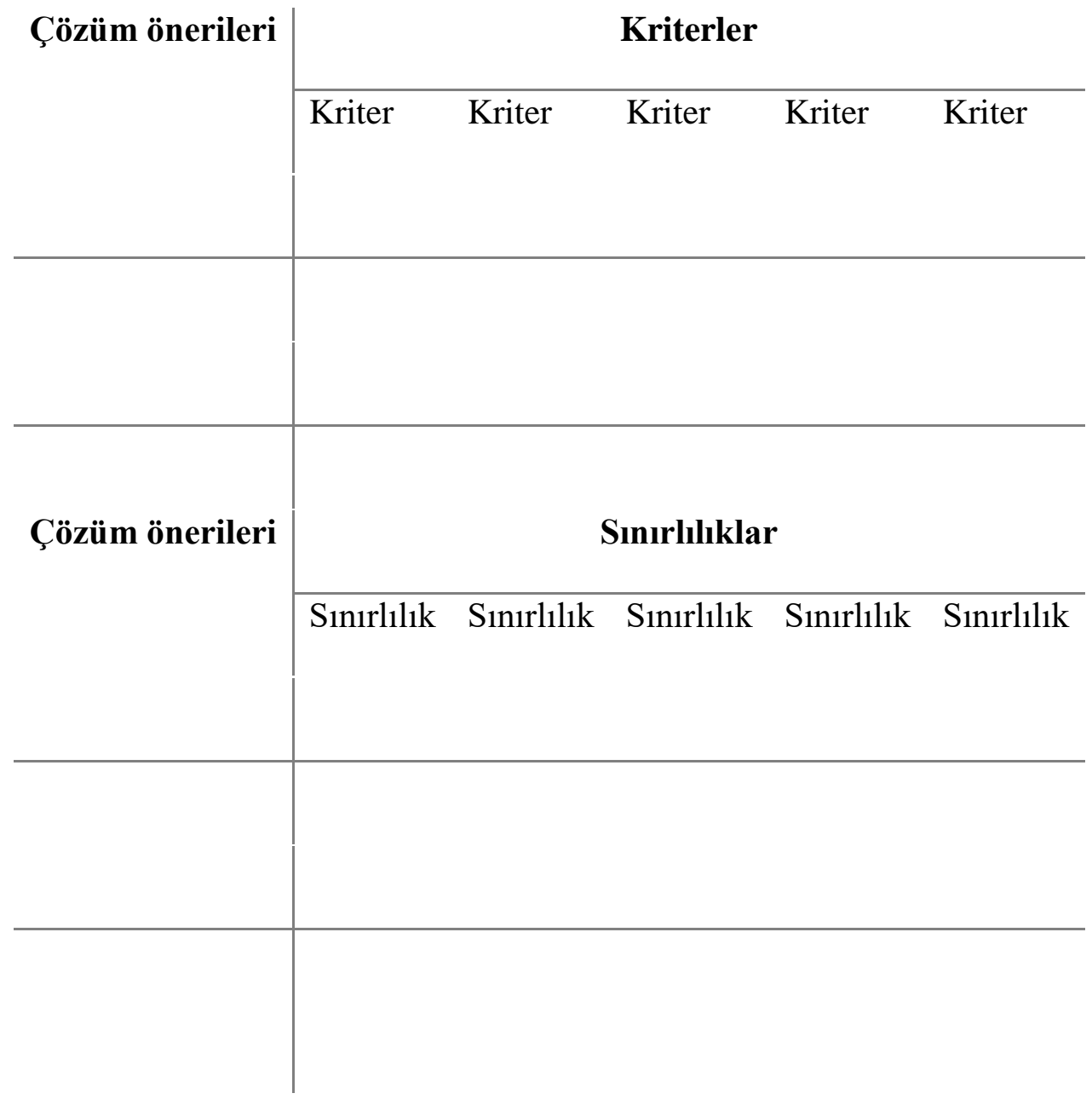


7. Pelin'in annesinin problemini çözecek aracın nasıl yapılacağına ve işleyeceğine dair aklınızda oluşan fikirleri aşağıdaki boş bırakılan yere çiziniz ve mümkünse prototipini yapınız.

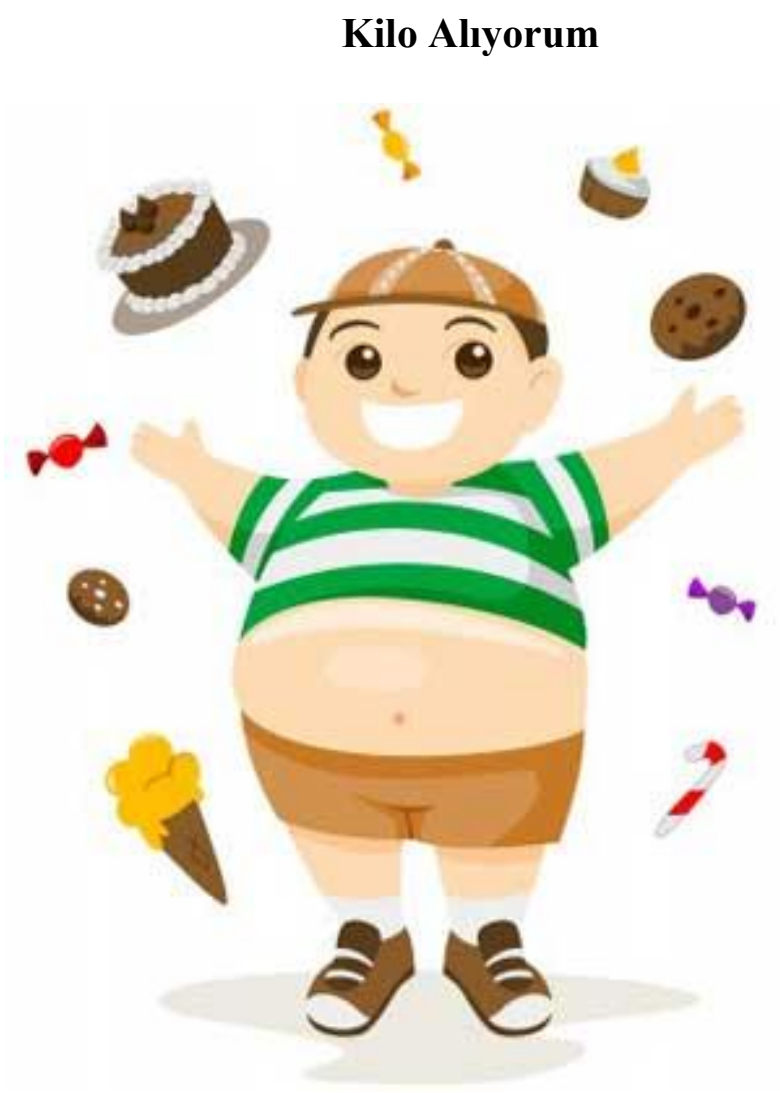

Problem Durumu: Ceren arkadaşlarıyla birlikte okulda, evde ve dışarıya çıktığında hamburger, çikolata, meyve suyu gibi yiyecekleri düzensiz bir şekilde yiyip içiyormuş. Zamanla hızlı bir şekilde kilo aldığını fark etmiş. Oysaki en yakın arkadaşı olan İlayda çok fazla kilo almıyormuş. Bunu fark eden Ceren, İlayda'nın bir alet yardımı ile yedikleri yiyeceklerin kalorilerini ölçtüğünü fark etmiş. İlayda bu şekilde günlük alması gereken kalorinin dışına çıkmıyormuş. Sizce Ceren de yiyeceklerin kalorilerini ölçen bir alet tasarlayabilir mi?

1. Ceren'in tasarlaması gereken aletin özellikleri nasıl olmalıdır? 
2. Ceren'in bulduğu çözümde yaşayacağı sınırlılıklar neler olabilir?

3. Ceren'in çözümüne ulaşabilmesi için ne gibi bilgilere ihtiyacı vardır?

4. Hangi kaynaklar kesinlikle Ceren'i çözüme götürür?

5. Ceren'in kilo alışını önleyecek alet için hangi malzemelere ihtiyaç var?

6. Kriter ve sınırlılık matrisleri seni çözümüne götürecek tasarımı bulman için yardımc1 olabilir?

7. Verilen tasarım görevini düşün. Ceren'in problemini ortadan kaldıracak aletin çizimini yapmanız ve bu tasarımın modeli ile sunum yapmanız gerekmektedir.

\section{Maruf Kasabası}

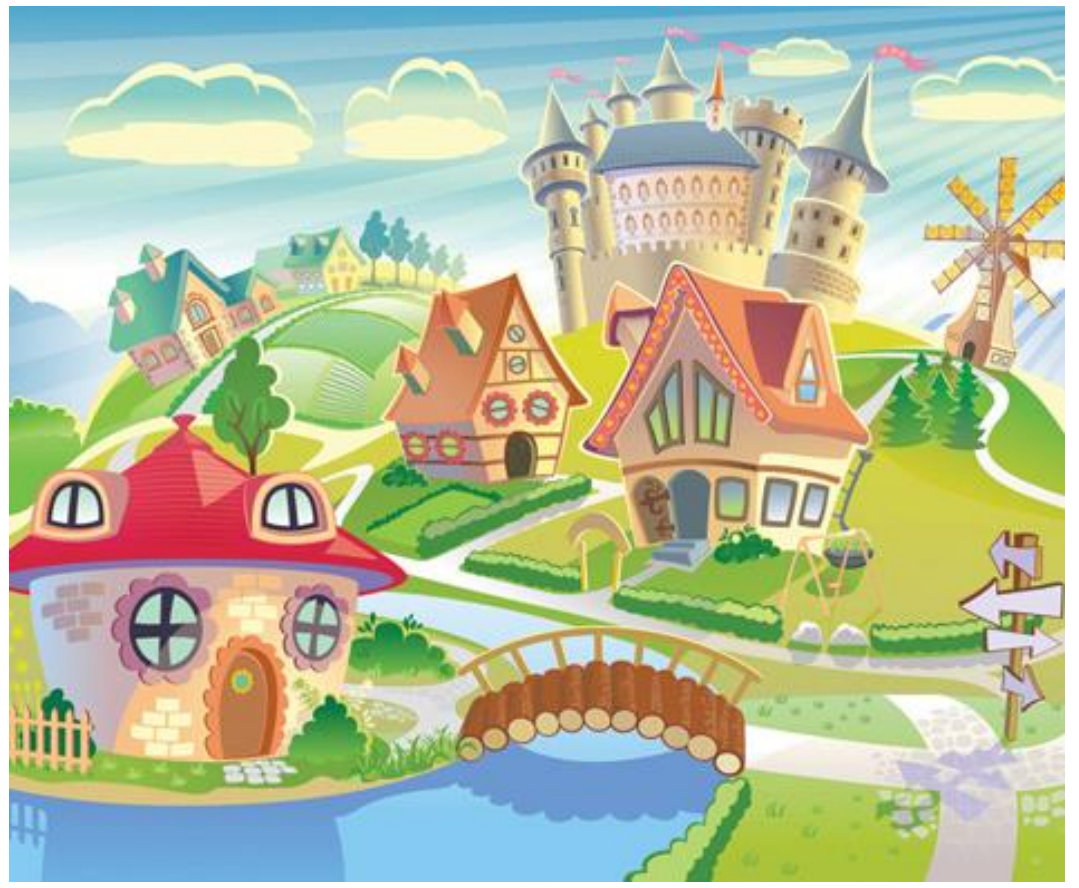

Problem Durumu: Kerem Maruf kasabasında yaşamaktadır. Kerem'in yaşadığı bu kasabada İkikoru ırmağı bulunmaktadır. Bu ırmağın suları azgın ve çok dalgalıdır. Kasabanın yer şekillerinden dolayı iki yaka arasına köprü yapmanın imkânı yoktur. Kasabada 
yaşayanlar ırmaktan karşıya geçmek için sandallardan yararlanmaktadırlar. Bu da çok sayıda insan ve eşya kaybına neden olmaktadır. Bu olaylara şahit olan Kerem oturur ve düşünmeye başlar. Kerem bu durumu nasıl çözebilir?

1. Kerem'in daha fazla can ve mal kayıplarına yol açmamak adına bulduğu çözüm yollarının özellikleri nasıl olmalıdır?

2. Kerem'in bulduğu çözüm yollarının sınırlılıkları neler olabilir?

3. Kerem'in bu duruma çözüm getirebilmesi için ne gibi bilgilere ihtiyacı vardır?

4. Buna göre can ve mal kaybını azaltmak için önerilen çözüm önerileri nelerdir?

5. Kriter ve sınırlılık matrisleri seni çözümüne götürecek tasarımı bulman için yardımcı olabilir.

6. Verilen büyük tasarım görevine göre, Kerem'in problemini çözecek çözüm önerisinin, boş bırakılan yere resmini çiziniz ve yapabiliyorsanız gerçeğe uygun modelini oluşturunuz. 